\title{
Erratum to: Aminochrome Induces Disruption of Actin, Alpha-, and Beta-Tubulin Cytoskeleton Networks in Substantia-Nigra- Derived Cell Line
}

Irmgard Paris - Carolina Perez-Pastene - Sergio Cardenas •

Patricio Iturriaga-Vasquez • Patricia Muñoz •

Eduardo Couve $\cdot$ Pablo Caviedes $\cdot$ Juan Segura-Aguilar

Published online: 4 February 2010

(C) Springer Science+Business Media, LLC 2010

Erratum to: Neurotox Res

DOI 10.1007/s12640-009-9148-4

The name of one of the authors, Patricio Iturriaga-Vasquez, was spelled incorrectly.

The online version of the original article can be found under doi:10.1007/s12640-009-9148-4.

I. Paris - C. Perez-Pastene $\cdot$ S. Cardenas · P. Muñoz ·

P. Caviedes · J. Segura-Aguilar ( $\square)$

Program of Molecular and Clinical Pharmacology,

Faculty of Medicine, ICBM, Independencia1027,

Casilla, Santiago 70000, Chile

e-mail: jsegura@med.uchile.cl

P. Iturriaga-Vasquez

Department of Chemistry, Faculty of Sciences,

University of Chile, Santiago, Chile

I. Paris

Universidad Santo Tomás, Vina del Mar, Chile

E. Couve

University of Valparaiso, Valparaiso, Chile 